\title{
Characterization of stockpiled phosphogypsum waste in Santos basin, Brazil
}

\author{
A.J.G. Santos, B.P. Mazzilli and D.I.T. Favaro ${ }^{1}$ \\ Instituto de Pesquisas Energéticas e Nucleares, Departamento de Radioproteçao Ambiental, \\ Caixa Postal 11049, Sao Paulo, Brazil \\ ${ }^{1}$ Laboratorio de Analise por Ativaçao, Caixa Postal 11049, Sao Paulo, Brazil
}

\begin{abstract}
Phosphogypsum is a waste produced by the phosphate fertiliser industry. It is formed by precipitation during wet sulphuric acid processing of phosphate rocks. Although phosphogypsum is mainly calcium sulphate dihydrate, it contains elevated levels of impurities, which originate from the source phosphate rock used in the phosphoric acid production. Among these impurities, radionuclides from U-238 and Th-232 decay series, particularly Ra-226, Ra-228 and $\mathrm{Pb}-210$, are of most concern due to their radiotoxicity. The phosphate fertiliser complex located in Santos Basin, Southwest Brazil, is responsible for the production of approximately 2000 tons of phosphogypsum per day. This phosphogypsum waste is stockpiled and presents a potential threat to the surrounding environment. This study aims to determine the activity concentration of Ra-226, Ra-228, $\mathrm{Pb}-210$ and $\mathrm{K}-40$ in the stockpiled phosphogypsum of the two main local producers. As a complementary study, trace and microelements $\mathrm{Ba}, \mathrm{Co}, \mathrm{Cr}, \mathrm{Fe}, \mathrm{Hf}, \mathrm{Sb}, \mathrm{Sc}, \mathrm{Ta}, \mathrm{Th}, \mathrm{U}$, and rare earths $\mathrm{Ce}, \mathrm{Eu}, \mathrm{La}, \mathrm{Lu}, \mathrm{Nd}, \mathrm{Sm}, \mathrm{Tb}$ and $\mathrm{Yb}$ ) were also determined by instrumental neutron activation analysis (INAA). Mean activity concentrations of $401 \pm 108 \mathrm{Bqkg}^{-1}, 173 \pm 65 \mathrm{Bqkg}^{-1}$ and $389 \pm 106 \mathrm{Bqkg}^{-1}$ were observed for Ra226, Ra-228 and $\mathrm{Pb}-210$ for one producer. The results obtained for the second producer were $840 \pm 275 \mathrm{Bqkg}^{-1}, 225 \pm 32$ $\mathrm{Bqkg}^{-1}$ and $827 \pm 276 \mathrm{Bqkg}^{-1}$ for Ra-226, Ra-228 and $\mathrm{Pb}-210$, respectively. Phosphogypsum samples are enriched in rareearths elements, specifically $\mathrm{Ce}, \mathrm{Eu}, \mathrm{La}, \mathrm{Nd}, \mathrm{Sm}$, and $\mathrm{Tb}$, and the elements $\mathrm{Ba}$ and $\mathrm{Ta}$. The radiochemical and elemental characterisation of the phosphogypsum from industry $\mathrm{A}$ and $\mathrm{C}$ show that the stacks are quite homogeneous and mainly dependent upon the origin of the phosphatic rock used as raw material. This information is important and necessary for decision making on possible uses of this waste. The radionuclides $\mathrm{Ra}$ and $\mathrm{Pb}$, which present high radiotoxicity, although present in the phosphogypsum, are not available for the surrounding environment.
\end{abstract}

\section{INTRODUCTION}

The presence of natural radionuclides in mineral ores and their redistribution in products and wastes has been well known. Among industrial wastes containing technologically enhanced naturally occurring radioactive materials (TENORM), excluding those generated by nuclear technology, of particular concern is phosphogypsum. This waste is produced world-wide in amounts of the order of 300 million tons per year, thus posing serious problems with its utilisation and safe disposal. In Brazil, several phosphate industries are responsible for the production of approximately 69 million tons of phosphogypsum waste. The two main industries located in Santos Basin, named " $\mathrm{A}$ " and "C", are responsible for the production of approximately 2000 tons of phosphogypsum per day [1]. No regulation in terms of radiation protection principles has been applied to these industries so far; as a consequence, members of the public may incur undue exposures.

The fundamental reaction in the phosphate fertiliser industry can be summarised by the following equation:

$$
\mathrm{Ca}_{10}\left(\mathrm{PO}_{4}\right)_{6} \mathrm{~F}_{2}+10 \mathrm{H}_{2} \mathrm{SO}_{4}+20 \mathrm{H}_{2} \mathrm{O} \rightarrow 10 \mathrm{CaSO}_{4} \cdot 2 \mathrm{H}_{2} \mathrm{O}+6 \mathrm{H}_{3} \mathrm{PO}_{4}+2 \mathrm{HF}
$$

During this process the radioactive equilibrium between $U, T h$ and their decay products is disrupted and the radionuclides migrate according to their solubility: uranium isotopes forms highly soluble compounds with the ion $\left(\mathrm{PO}_{4}\right)^{3-}$ while $\mathrm{Ra}$ and $\mathrm{Th}$ isotopes, $\mathrm{Pb}-210$ and $\mathrm{Po}-210$ concentrate into phosphogypsum [2].

While the ideal mole ratio between gypsum and phosphoric acid is 5:3 in the wet phosphoric acid process, the mass ratio is about $3: 1$; that means that the amount of gypsum produced correspond to three times the amount of acid. Phosphogypsum produced during the process is filtered off and pumped as slurry to nearby ponds, where it stays for a period sufficient to allow complete deposition. This waste is then moved to nearby storage areas, the so-called "gyp-stacks".

Although phosphogypsum is used in somc countries for production of cement, construction materials and as a soil amendment in agricultural lands, its commercial use in Brazil is not well defined. This restriction is mainly due to the impurities contained in phosphogypsum, particularly $\mathrm{Ra}$ and $\mathrm{Th}$ isotopes: 
${ }^{210} \mathrm{~Pb}$ and $210 \mathrm{Po}$ derived from the $\mathrm{U}$ and $\mathrm{Th}$ series present in the phosphate rock. Besides the obvious waste of potentially valuable by-product, the main problem associated with phosphogypsum storage is the potential threat to the surrounding environment, specifically air and water resources in the vicinity of gypsum stacks. The most critical pathways between phosphogypsum and the public are, therefore, through inhalation of radon and through groundwater contamination.

This paper aims to determine the activity concentration of ${ }^{226 \mathrm{Ra}},{ }^{228 \mathrm{Ra}},{ }^{210 \mathrm{~Pb}}$ and ${ }^{40 \mathrm{~K}}$ in the stockpiled phosphogypsum of the two main local producers of phosphoric acid. Multielemental analysis of the phosphogypsum samples was also performed, by using instrumental neutron activation analysis (INAA) technique. Since one of the prime concerns about phosphogypsum storage is the potential for contamination of fresh water aquifers underlying the stacks, water from monitor wells located in the nearby was also collected for radionuclides determination.

\section{MATERIAL AND METHODS}

Phosphogypsum samples from stacks and water samples from monitor wells were collected in points depicted in Figure 1. In order to get information about radionuclides distribution throughout the deposit, cores ( 1 to $2.5 \mathrm{~m}$ in depth) were collected at different layers, from the surface to the bottom of the stacks. Stack from industry A was drilled in 19 different locations, whereas stacks from industry C were drilled in 10 different locations. The location of the sampling points were established by GPS (global positioning system) technique.

It is known that water exists in the crystalline lattice of both dihydrate and hemihydrate forms of phosphogypsum and there exist differences of up to $15.7 \%$ between the formula weights. Therefore, in order to get reliable results, the way the samples were dried and homogenised was extremely important, since all the radiochemical analysis performed are based upon gravimetric determinations. All the phosphogypsum samples studied were, therefore, prepared by drying at a temperature not greater than $105^{\circ} \mathrm{C}$ to constant mass, ground to a grain-size of less than $250 \mu \mathrm{m}$ and finally stored in a desiccator at room temperature. Water samples were filtered and concentrated to a final volume of $100 \mathrm{ml}$.

Activity concentrations of ${ }^{228} \mathrm{Ra},{ }^{226} \mathrm{Ra}$ and ${ }^{40 \mathrm{~K}}$ were measured in samples of phosphogypsum and water by gamma spectrometry with a hyper-pure germanium detector, GEM-15200, from EG\&G Ortec. The detector was calibrated using natural soil, rock and water spiked with radionuclides certified by Amersham. Samples were packed in $100 \mathrm{~cm}^{3}$ cans and sealed for about four weeks prior to the measurement in order to ensure that equilibrium has been reached between ${ }^{226} \mathrm{Ra}$ and its decay products of short half-life. The ${ }^{226 \mathrm{Ra}}$ activities were determined by taking the mean activity of three separate photopeaks of its daughter nuclides: ${ }^{214} \mathrm{~Pb}$ at $295 \mathrm{keV}$ and $352 \mathrm{keV}$, and ${ }^{214} \mathrm{Bi}$ at $609 \mathrm{keV}$. The ${ }^{228 \mathrm{Ra}}$ content of the samples was determined by measuring the intensities of the $911 \mathrm{keV}$ and $968 \mathrm{keV}$ gamma-ray peaks from ${ }^{228} \mathrm{Ac}$. The potassium content was determined from the $1460 \mathrm{keV}$ gamma-ray peak of ${ }^{40 \mathrm{~K}}$. Typical lower limits of detection for gamma spectrometry were $0.17 \mathrm{~Bq} / \mathrm{kg}$ for ${ }^{226 \mathrm{Ra}}, 0.59 \mathrm{~Bq} / \mathrm{kg}$ for ${ }^{228 \mathrm{Ra}}$ and $4.2 \mathrm{~Bq} / \mathrm{kg}$ for ${ }^{40 \mathrm{~K}}$, for a counting time of 50,000 seconds.

The concentration of $210 \mathrm{~Pb}$ was carried out by measuring the activity of its low energy peak $(47 \mathrm{keV})$ in homogenised samples in a coaxial germanium detector, EGNC 15-190-R, from Eurisys. Samples were packed in $100 \mathrm{~cm}^{3}$ cans and counted for 50,000 seconds. Self-absorption correction was applied since the attenuation for low energy gamma rays is highly dependent upon sample composition. The approach used was modified from that suggested by Cutshall et al. [3]. According to them, the selfabsorption equation may be written as:

$$
A / O=\frac{\ln \left(\frac{T}{I}\right)}{\left(\frac{T}{I}-1\right)}
$$


Where $\mathrm{O}$ is the attenuated sample output (count rate), $\mathrm{A}$ is the actual sample photon emission rate, $\mathrm{T}$ and $I$ are the beam intensities transmitted through the sample and standard, respectively. The attenuated beam intensity $(\mathrm{T})$ is defined as the difference between the count rate of each sample with and without an external source containing $210 \mathrm{~Pb}$ centred on top of the sample container. The factor I was determined by making a measurement with the same external ${ }^{210} \mathrm{~Pb}$ source placed on top of the efficiency standard. This ratio thus represents how each sample compares to the efficiency standard in terms of self-absorption. The final $210 \mathrm{~Pb}$ activities are then obtained by substituting the relative absorption factor into the activity calculation equation, as follows:

$$
A(B q / k g)=\frac{(C-C o) \cdot f a b s}{W t . \eta \cdot T \cdot \gamma}
$$

Where $\mathrm{A}$ is the sample activity, $\mathrm{C}$ and Co are the sample and background counts, Wt is the sample weight in $\mathrm{kg}$, fabs is the relative absorption factor, $\eta$ is the efficiency in cps/dps, $T$ is the counting time in seconds and $\gamma$ is the peak intensity. The lower limit of detection obtained for ${ }^{210} \mathrm{~Pb}$ was $20.6 \mathrm{~Bq} / \mathrm{kg}$, for a counting time of 50,000 seconds.

For the multielemental analysis of samples, approximately $200 \mathrm{mg}$ of phosphogypsum (duplicate samples) and about $150 \mathrm{mg}$ of reference material (standard MR IWG-GIT Granite AC-E) were accurately weighed and sealed in pre-cleaned double polyethylene bags, for irradiation. Phosphogypsum samples and reference material were irradiated for 16 hours, under a thermal neutron flux of $10^{12} \mathrm{n} \mathrm{cm}^{-2} \mathrm{~s}^{1}$ in the IEARlm nuclear reactor at IPEN. Two series of counting were made: the first, after one week decay and the second, after 15-20 days. The counting time was 1.5 hours for each sample and reference material. Gamma spectrometry was performed using an Intertechnique hyperpure Ge detector and associated electronics, with a resolution of $0.88 \mathrm{keV}$ and $1.90 \mathrm{keV}$ for ${ }^{57} \mathrm{Co}$ and ${ }^{60} \mathrm{Co}$, respectively. The analysis of the data was made by Omnigam Spectrum Analysis to identify the gamma-ray peaks. Trace and micro elements ( $\mathrm{Ba}, \mathrm{Co}, \mathrm{Cr}, \mathrm{Fe}$, $\mathrm{Hf}, \mathrm{Sb}, \mathrm{Sc}, \mathrm{Ta}, \mathrm{Th}, \mathrm{U}$ and rare earths $\mathrm{Ce}, \mathrm{Eu}, \mathrm{La}, \mathrm{Lu}, \mathrm{Nd}, \mathrm{Sm}, \mathrm{Tb}$ and $\mathrm{Yb}$ ) were determined by instrumental neutron activation analysis.

\section{RESULTS AND DISCUSSION}

The results obtained for the activity concentration of ${ }^{226} \mathrm{Ra},{ }^{228} \mathrm{Ra},{ }^{210} \mathrm{~Pb}$ and ${ }^{40} \mathrm{~K}$ are presented in Table 1 for industry $\mathrm{C}$ and in Table 2 for industry A. Cluster analysis was performed in order to verify the homogeneity of the phosphogypsum samples, from stacks $A$ and $B$ (Figure 2 and 3 , respectively). Samples of phosphogypsum $\mathrm{C} 6, \mathrm{C} 8$ and $\mathrm{C} 10$ from industry $\mathrm{C}$ and samples A5, A9 and A10 from industry A represents different groups with no similarities with the other analysed samples. Their composition and physical characteristics indicate that: a) these samples are a mixture of phosphogypsum, soil and clay or b) these samples are probably originated from phosphate rocks from other countries. Average concentrations were evaluated, disregarding these samples and considering only samples representative of Brazilian phosphogypsum. Mean activity concentrations of $401 \pm 108 \mathrm{Bqkg}^{-1}, 173 \pm 65 \mathrm{Bqkg}^{-1}$ and $389 \pm 106 \mathrm{Bqkg}^{-1} \mathrm{were}$ observed for ${ }^{226 \mathrm{Ra},}{ }^{228} \mathrm{Ra}$ and ${ }^{210} \mathrm{~Pb}$ in industry $\mathrm{C}$. The results obtained for producer A were $845 \pm 266 \mathrm{Bqkg}$, $232 \pm 41 \mathrm{Bqkg}^{-1}$ and $834 \pm 267 \mathrm{Bqkg}^{-1}$ for ${ }^{226 \mathrm{Ra},}{ }^{228} \mathrm{Ra}$ and ${ }^{210 \mathrm{~Pb}}$, respectively. These results agree well with previous determination of the same radionuclides in fresh phosphogypsum by Mazzilli et al [2], showing that the radioactivity present in the stockpiled phosphogypsum is mainly dependent on the amount supplied by the ore rock, which is different for the two industries. 
Table 1: Activity concentrations of ${ }^{228} \mathrm{Ra},{ }^{226} \mathrm{Ra},{ }^{210} \mathrm{~Pb}$ and ${ }^{40} \mathrm{~K}$ in phosphate rock (PR) and phosphogypsum (PG) from producer C and soil $\left(\mathrm{Bq} \mathrm{kg}^{-1}\right)$.

\begin{tabular}{|c|c|c|c|c|c|}
\hline Samples & Collecting date & ${ }^{228} \mathrm{Ra}$ & $226 \mathrm{Ra}$ & $210 \mathrm{~Pb}$ & ${ }^{40} \mathrm{~K}$ \\
\hline PR C & $06 / 19 / 2000$ & $221_{ \pm} 28$ & $427 \pm 47$ & $422 \pm 29$ & $<4$ \\
\hline $\mathrm{PGCl}$ & & $130_{ \pm} 16$ & $350 \pm 42$ & $353 \pm 31$ & $<52$ \\
\hline $\mathrm{C} 2$ & & $90_{ \pm} 12$ & $594 \pm 65$ & $581 \pm 35$ & $<43$ \\
\hline $\mathrm{C} 3$ & & $229_{ \pm} 19$ & $436 \pm 62$ & $422 \pm 28$ & $<61$ \\
\hline $\mathrm{C} 4$ & & $238 \pm 21$ & $307 \pm 48$ & $303 \pm 15$ & $<55$ \\
\hline $\mathrm{C} 5$ & & $214_{ \pm} 19$ & $337 \pm 42$ & $318 \pm 19$ & $15 \pm 1$ \\
\hline $\mathrm{C6}^{*}$ & $09 / 27 / 2000$ & $87 \pm 7$ & $56 \pm 4$ & $49 \pm 3$ & $<92$ \\
\hline$\overline{C 7}$ & & $\overline{96 \pm 6}$ & $480 \pm 36$ & $464_{ \pm} 33$ & $<95$ \\
\hline C8* & & $<12$ & $177_{ \pm 14}$ & $159_{ \pm} 13$ & $<88$ \\
\hline$\overline{\mathrm{Cg}}$ & & $217 \pm 19$ & $303 \pm 22$ & $287 \pm 17$ & $<91$ \\
\hline C10* & & $98 \pm 7$ & $59 \pm 4$ & $43 \pm 4$ & $<78$ \\
\hline \multicolumn{2}{|c|}{ Mean \pm standard deviation } & $173_{ \pm} 65$ & $401 \pm 108$ & $389 \pm 106$ & - \\
\hline \multicolumn{2}{|c|}{ Soil** } & $62 \pm 24$ & $88 \pm 31$ & - & $454_{ \pm} 173$ \\
\hline
\end{tabular}

* Results not considered in the evaluation of the arithmetic mean

** Results for soil represent the arithmetic mean of 8 soil samples collected in the surrounding environment of industry A and $C$

Table 2 Activity concentrations of ${ }^{228} \mathrm{Ra},{ }^{226 \mathrm{Ra}},{ }^{210} \mathrm{~Pb}$ and $40 \mathrm{~K}$ in water samples from the monitor wells $(\mathrm{Bq} \mathrm{L}-1)$.

\begin{tabular}{|c|c|c|c|c|c|}
\hline $\begin{array}{l}\text { Sampling } \\
\text { location }\end{array}$ & $\begin{array}{l}\text { Collecting } \\
\text { date }\end{array}$ & ${ }^{228} \mathrm{Ra}$ & ${ }^{226} \mathrm{Ra}$ & $210 \mathrm{~Pb}$ & ${ }^{40} \mathrm{~K}$ \\
\hline MW 02 & $06 / 20 / 2000$ & $8.0_{ \pm} 0.4$ & $1.7 \pm 0.1$ & $<1.6$ & $8.1 \pm 0.4$ \\
\hline MW 03 & & $4.5 \pm 0.2$ & $1.2 \pm 0.1$ & $2.0 \pm 0.1$ & $7.9_{ \pm} 0.5$ \\
\hline MW 04 & & $4.8 \pm 0.2$ & $1.2 \pm 0.1$ & $3.1 \pm 0.2$ & 4.1 \\
\hline MW 05 & & $6.7 \pm 0.3$ & $2.9 \pm 0.2$ & $<1.6$ & $11 \pm 1$ \\
\hline MW02 & $09 / 28 / 2000$ & $<0.9$ & $1.1 \pm 0.1$ & $1.1 \pm 0.1$ & 4.1 \\
\hline MW03 & & $3.1 \pm 0.1$ & $1.2 \pm 0.1$ & $<1.6$ & $<4.1$ \\
\hline MW 04 & & $1.4 \pm 0.1$ & $1.5 \pm 0.1$ & $<1.6$ & $<4.1$ \\
\hline \multicolumn{2}{|c|}{ Mean \pm standard deviation } & $4.1 \pm 2.6$ & $1.5 \pm 0.6$ & $1.8 \pm 1.4$ & - \\
\hline
\end{tabular}


In Table 3 are presented results obtained for the activity concentration of ${ }^{228} \mathrm{Ra},{ }^{226} \mathrm{Ra}$ and ${ }^{210} \mathrm{~Pb}$ in water samples collected in the monitor wells depicted in Figure $1 .{ }^{226} \mathrm{Ra}$ and ${ }^{210} \mathrm{~Pb}$ mean concentrations did not exceed 1.8 Bq L-1 , whereas mean activity of $4,1 \mathrm{~Bq} \mathrm{~L} \mathrm{~L}^{-1}$ was observed for ${ }^{228} \mathrm{Ra}$. The results obtained for the mean activity concentrations of ${ }^{228} \mathrm{Ra}$ and $210 \mathrm{~Pb}$ in the monitor wells are of the same order of magnitude than the recommended radioactivity drinking water standards for gross-beta activity $\left(1 \mathrm{~Bq} \mathrm{~L}^{-1}\right)$ [4]. For ${ }^{226 \mathrm{Ra}}$ the mean activity concentration is 20 times higher than the recommended radioactivity drinking water standards for gross-alpha activity $\left(0.1 \mathrm{~Bq} \mathrm{~L}^{-1}\right)$ [4]. Oliveira et al [5] measuring the activity concentration of $226 \mathrm{Ra}$ in drinking water supplies of São Paulo State, found concentrations ranging from $<2.2$ to $235 \mathrm{mBq} \mathrm{L} \mathrm{I}^{-1}$; with four locations presenting ${ }^{226} \mathrm{Ra}$ activity higher than $0.1 \mathrm{~Bq} \mathrm{~L}-1$. Recent papers $[6,7,8]$ are concerned with the potential release of radionuclides from phosphogypsum to the aquatic environment. Burnett and Elzerman [6]

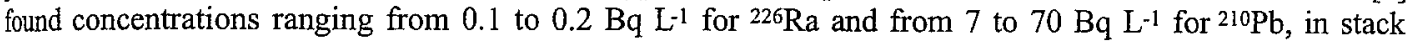
fluids in Florida.

Table 3 Activity concentrations of ${ }^{228} \mathrm{Ra},{ }^{226} \mathrm{Ra},{ }^{210} \mathrm{~Pb}$ and ${ }^{40} \mathrm{~K}$ in phosphate rock (PR) and phosphogypsum (PG) from producer $\mathrm{A}$ (Bq $\mathrm{kg}^{-1}$ ).

\begin{tabular}{|c|c|c|c|c|c|}
\hline Samples & $\begin{array}{l}\text { Collecting } \\
\text { date }\end{array}$ & ${ }^{228} \mathrm{Ra}$ & ${ }^{226} \mathrm{Ra}$ & $210 \mathrm{~Pb}$ & $40 \mathrm{~K}$ \\
\hline PR A & $06 / 20 / 2000$ & $260 \pm 27$ & $638 \pm 61$ & $645 \pm 39$ & $19 \pm 1$ \\
\hline PG A1 & & $280 \pm 27$ & $773 \pm 72$ & $\overline{761} \pm 45$ & $<6$ \\
\hline$\overline{\mathrm{A} 2}$ & & $238 \pm 26$ & $762 \pm 61$ & $748 \pm 53$ & $<57$ \\
\hline A3 & & $215_{ \pm 19}$ & $849 \pm 78$ & $864 \pm 69$ & $22 \pm 2$ \\
\hline A4 & & $269 \pm 32$ & $603 \pm 27$ & $592 \pm 41$ & $<53$ \\
\hline $\mathrm{AS}^{*}$ & & $139_{ \pm} 12$ & $282 \pm 24$ & $267 \pm 16$ & $288_{ \pm} 15$ \\
\hline A6 & & $255_{ \pm 2} 8$ & $1013 \pm 84$ & $1005 \pm 81$ & $153 \pm \mathrm{I}$ \\
\hline A7 & & $219 \pm 23$ & $935_{ \pm} 87$ & $917 \pm 55$ & $28 \pm 2$ \\
\hline A8 & & $198_{ \pm} 17$ & $1251 \pm 132$ & $1234 \pm 63$ & $<57$ \\
\hline A9* & & $96 \pm 11$ & $82 \pm 7$ & $77 \pm 4$ & $460 \pm 32$ \\
\hline A10* & & $87 \pm 10$ & $59 \pm 8$ & $68 \pm 4$ & $285 \pm 16$ \\
\hline A11 & & $263 \pm 22$ & $558 \pm 62$ & $539 \pm^{43}$ & $<53$ \\
\hline $\mathrm{A} 12$ & $09 / 28 / 2000$ & $202_{ \pm} 16$ & $1117 \pm 85$ & $1105 \pm 88$ & $<106$ \\
\hline A13 & & $246+27$ & $538_{ \pm} 39$ & $552 \pm 47$ & $<78$ \\
\hline A14 & & $218 \pm 19$ & $871 \pm 62$ & $853 \pm 43$ & $<81$ \\
\hline A15 & & $214 \pm 26$ & $473 \pm 29$ & $438 \pm 28$ & $370 \pm 26$ \\
\hline A16 & & $211 \pm 24$ & $472 \pm 33$ & $451 \pm 27$ & $<75$ \\
\hline A17 & & $334 \pm 32$ & $928 \pm 71$ & $951 \pm 76$ & $<80$ \\
\hline A18 & & $191_{ \pm} 16$ & $1101 \pm 75$ & $1089 \pm 65$ & $<70$ \\
\hline A.19 & & $163 \pm 15$ & $1282 \pm 115$ & $1257 \pm 75$ & $<104$ \\
\hline \multicolumn{2}{|c|}{ Mean \pm standard deviation } & $232 \pm 41$ & $845_{ \pm} 266$ & $834 \pm 267$ & - \\
\hline
\end{tabular}

\footnotetext{
* Results not considered in the evaluation of the arithmetic mean
} 
Tables 4 and 5 show the results obtained for multielemental analysis of phosphogypsum and phosphate rock samples by INAA. The precision based in duplicate samples analysis was better than $10 \%$. Here too, the results obtained for elemental concentration in samples A5, A9 and A10 (Table 5) and C6, C8 and $\mathrm{Cl}$ (Table 4) presented a different pattern, confirming that the raw material used in the manufacturing of this phosphoric acid came from other locations or that the phosphogypsum samples were mixed with soil and clay in the stacks. Phosphogypsum samples are enriched in rare-earth elements, specifically $\mathrm{Ce}, \mathrm{Eu}, \mathrm{La}, \mathrm{Nd}$, $\mathrm{Sm}$, and $\mathrm{Tb}$, and the elements $\mathrm{Ba}$ and $\mathrm{Ta}$.

Table 4 Concentrations of elements determined by INAA in phosphate rock (PR) and phosphogypsum (PG) from producer $\mathrm{C}\left({ }_{\mu} \mathrm{g} \mathrm{g}^{-1}\right)$.

\begin{tabular}{|c|c|c|c|c|c|c|c|c|c|}
\hline Sample & La & Sm & Nd & Eu & $\mathbf{T b}$ & $\mathrm{Ce}$ & Lu & $\mathrm{Yb}$ & U \\
\hline PRC & $2284 \pm 120$ & $264 \pm 9$ & $2026 \pm 203$ & $67 \pm 4$ & $12 \pm 1$ & $4342 \pm 141$ & $0.37 \pm 0.02$ & $10 \pm 1$ & $\overline{41+4}$ \\
\hline PGC1 & $155 \pm 9$ & $23 \pm 1$ & $147 \pm 10$ & $5.2 \pm 0.3$ & $2.0 \pm 0.1$ & $307 \pm 13$ & $0.48 \pm 0.02$ & $2.6 \pm 0.1$ & $4.9+0.6$ \\
\hline C2 & $349 \pm 19$ & $49 \pm 2$ & $358 \pm 25$ & $13 \pm 1$ & $3.9 \pm 0.2$ & $639 \pm 25$ & $0.41 \pm 0.02$ & $3.3 \pm 0.1$ & $3.5+0.1$ \\
\hline $\mathrm{C3}$ & $1300_{ \pm} 70$ & $171 \pm 6$ & $1285 \pm 88$ & $36 \pm 2$ & $7.3 \pm 0.3$ & $2574 \pm 99$ & $0.11 \pm 0.01$ & $4.4 \pm 0.2$ & $2.9+0.3$ \\
\hline C4 & $1632 \pm 88$ & $149 \pm 5$ & $1722 \pm 174$ & $47 \pm 3$ & $10.1 \pm 0.5$ & $3387 \pm 129$ & $0.28 \pm 0.01$ & $4.3 \pm 0.2$ & $\frac{-}{3.4+0.3}$ \\
\hline C5 & $2373 \pm 125$ & $274 \pm 9$ & $1376 \pm 139$ & $46 \pm 3$ & $8.2 \pm 1.1$ & $3349_{ \pm} 109$ & $0.36 \pm 0.06$ & $9.8 \pm 0.6$ & $3.0+0.1$ \\
\hline
\end{tabular}

\begin{tabular}{|c|c|c|c|c|c|c|c|c|c|}
\hline Sample & $\mathbf{B a}$ & Co & $\mathrm{Cr}$ & Sb & Fe & Hf & Se & Ta & Th \\
\hline PRC & $15528 \pm 5287$ & $5.1 \pm 0.9$ & $34_{ \pm} 14$ & -- & $11892 \pm 356$ & $5.9 \pm 0.6$ & $29_{ \pm} 1$ & $21 \pm 2$ & $\overline{100+6}$ \\
\hline PGCI & $964 \pm 94$ & $1.2 \pm 0.6$ & $23 \pm 8$ & $0.7 \pm 0.1$ & $21387 \pm 707$ & $3.3 \pm 0.2$ & $8 \pm 4$ & $1.2 \pm 0.1$ & $17 \pm 1$ \\
\hline C2 & $1525 \pm 149$ & $0.14 \pm 0.07$ & $9 \pm 3$ & $0.5 \pm 0.1$ & $565 \pm 19$ & $3.4 \pm 0.3$ & $0.5 \pm 0.2$ & $1.1 \pm 0.1$ & $15_{ \pm} 1$ \\
\hline C3 & $2915 \pm 283$ & $0.10 \pm 0.05$ & $29 \pm 10$ & $1.1 \pm 0.2$ & $3996 \pm 149$ & $4.1 \pm 0.2$ & $4 \pm 2$ & $11 \pm 1$ & $43+2$ \\
\hline $\mathrm{C4}$ & $2839 \pm 283$ & $0.4 \pm 0.2$ & $20 \pm 7$ & $1.1_{ \pm 0.2}$ & $12447 \pm 508$ & $2.3 \pm 0.1$ & $3 \pm^{2}$ & $6 \pm 1$ & $66 \pm 3$ \\
\hline C5 & $5010 \pm 1706$ & $0.9 \pm 0.6$ & $29 \pm 12$ & $1.2 \pm 0.2$ & $2004 \pm 336$ & $1.2 \pm 0.4$ & $5.3 \pm 2.5$ & $6.9+1 . \overline{4}$ & $70 \pm \underline{3}$ \\
\hline
\end{tabular}

Table 5 Concentrations of elements determined by INAA in phosphate rock (PR) and phosphogypsum (PG) from producer $\mathrm{A}\left(\mu \mathrm{g} \mathrm{g}^{-1}\right)$.

\begin{tabular}{|c|c|c|c|c|c|c|c|c|c|}
\hline Sample & La & Sm & Nd & Eü & Tb & Ce & Lu & $\mathrm{Yb}$ & U \\
\hline PRA & $2002 \pm 106$ & $265 \pm 9$ & $1920 \pm 193$ & $65 \pm 4$ & $10.8 \pm 0.9$ & $4277 \pm 140$ & $0.59_{ \pm} 0.04$ & $7.9 \pm 0.4$ & $53 \pm 1$ \\
\hline PGAT & $1602 \pm 85$ & $208 \pm 7$ & $1093 \pm 105$ & $37 \pm 2$ & $7.0 \pm 0.6$ & $2333 \pm 76$ & $0.29 \pm 0.02$ & $6.5 \pm 0.3$ & $3.2 \pm$ \\
\hline A2 & $1221 \pm 65$ & $172 \pm 6$ & $1181 \pm 119$ & $41_{ \pm} 2$ & $9.0 \pm 0.8$ & $2628 \pm 86$ & $0.20 \pm 0.01$ & $4.8 \pm 0.3$ & $3.4 \pm$ \\
\hline$\overline{\mathrm{A} 3}$ & $807 \pm 41$ & $113 \pm 4$ & $1399 \pm 98$ & $43 \pm^{3}$ & $5.9 \pm 0.3$ & $2456 \pm 80$ & $0.17 \pm 0.01$ & $2.5 \pm 0.1$ & $2.9 \pm$ \\
\hline A4 & $974 \pm 36$ & $154 \pm 4$ & $1203 \pm 82$ & $41 \pm 5$ & $7.1 \pm 0.2$ & $2357 \pm 54$ & $0.22 \pm 0.01$ & $3.4 \pm 0.2$ & $3.6 \pm$ \\
\hline A5 & $59 \pm 3$ & $8.9 \pm 0.3$ & $75_{ \pm} 9$ & $2.0 \pm 0.1$ & $0,7 \pm 0,1$ & $1236 \pm 41$ & $0.28 \pm 0.02$ & $2.1 \pm 0.1$ & $2 \pm$ \\
\hline A6 & $1625 \pm 83$ & $158 \pm 6$ & $1409 \pm 98$ & $39 \pm 2$ & $7.5 \pm 0.3$ & $2877 \pm 94$ & $0.25 \pm 0.01$ & $5.0 \pm 0.2$ & $3 \pm$ \\
\hline A7 & $1256 \pm 47$ & $128 \pm 3$ & $1087 \pm 54$ & $41_{ \pm} 5$ & $5.4 \pm 0,2$ & $2523 \pm 58$ & $0.15 \pm^{0.01}$ & $2.5 \pm 0.1$ & $4.3 \pm 0$ \\
\hline A8 & $939 \pm 47$ & $129 \pm 5$ & $1511_{ \pm} 159$ & $34 \pm 2$ & $7.1 \pm 0.4$ & $1998 \pm 63$ & $0.18 \pm 0.01$ & $3.7 \pm 0.2$ & $2.6 \pm$ \\
\hline A9 & $38 \pm 2$ & $6.7 \pm 0.2$ & $35 \pm 4$ & $0.94 \pm 0.05$ & $1.2 \pm 0.1$ & $83 \pm 3$ & $0.55 \pm 0.03$ & $3.6 \pm 0.3$ & $3.2 \pm$ \\
\hline A10 & $36 \pm 2$ & $6.4 \pm 0.2$ & $30 \pm 2$ & $0.5 \pm 0.8$ & $0.7 \pm 0.1$ & $76 \pm 3$ & $0.34 \pm 0.02$ & $2.1 \pm 0.2$ & $1.6 \pm$ \\
\hline A11 & $1311 \pm 66$ & $170 \pm 6$ & $1378 \pm 104$ & $16 \pm 1$ & $9.2 \pm 0.5$ & $2588_{ \pm} 82$ & $0.29 \pm 0.01$ & $5.4 \pm 0.2$ & $2.8 \pm 0$ \\
\hline Sample & $\mathbf{B a}$ & Co & $\mathrm{Cr}$ & Sb & Fe & Hf & $\mathrm{Sc}$ & Ta & Th \\
\hline PRA & $1207 \pm 128$ & $4.7 \pm 2.9$ & $30_{ \pm} 12$ & -- & $2156 \pm 44$ & $2.3 \pm 0.2$ & $21_{ \pm} 10$ & $24 \pm 3$ & $77 \pm 4$ \\
\hline PGA1 & $1810 \pm 618$ & $0.8 \pm 0.5$ & $24_{ \pm}+10$ & -- & $23 \overline{72 \pm 78}$ & $2.3 \pm 0.2$ & $4 \pm 2$ & $8 . \overline{9} \pm 0.8$ & $70 \pm 3$ \\
\hline $\mathbf{A 2}$ & $10433 \pm 3552$ & $1 . \overline{1} 0.7$ & $22 \pm 9$ & $0.3 \pm 0.5$ & $788 \pm 29$ & $1.6 \pm 0.1$ & $3 \pm 1$ & $7.2 \pm 0.8$ & $72 \pm$ \\
\hline A3 & $7046 \pm 654$ & $5.2 \pm 3.2$ & $22 \pm 8$ & $0.6 \pm 0.1$ & $2156 \pm 44$ & $2.2 \pm 0.1$ & $3 \pm 1$ & $9.1 \pm 0.6$ & $62 \pm$ \\
\hline A4 & $8192 \pm 761$ & $3.4 \pm 1.7$ & $26 \pm 7$ & $0.8 \pm 0.1$ & $1347 \pm 30$ & $2.3 \pm 0.1$ & $3 \pm 1$ & $7.2 \pm 0.3$ & $64 \pm$ \\
\hline A5 & $683 \pm 73$ & $23 \pm 11$ & $39 \pm 14$ & $0.7 \pm 0.1$ & $37419 \pm 724$ & $4.5 \pm 0.4$ & $17 \pm 8$ & $1.4 \pm 0.1$ & $12 \pm$ \\
\hline A6 & $4992 \pm 465$ & $6.1 \pm 4.3$ & $28 \pm 10$ & $0.8 \pm 0.2$ & $2285 \pm 37$ & $1.3 \pm 0.1$ & $4 \pm 2$ & $8.8 \pm 0.6$ & $69 \pm$ \\
\hline A7 & $3744 \pm 248$ & $1.3 \pm 0.6$ & $19 \pm 7$ & $0.8 \pm 0.1$ & $128 \pm 3$ & $1.6 \pm 0.1$ & $1.2 \pm 0.5$ & $2.3 \pm 0.1$ & $85 \pm^{2}$ \\
\hline A8 & $7622 \pm 743$ & $7.3 \pm 3.6$ & $175 \pm 62$ & $0.4 \pm 0.1$ & $1368 \pm 64$ & $2.3 \pm 0.1$ & $4 \pm 2$ & - & $51+2$ \\
\hline A9 & $430 \pm 44$ & $17 \pm 12$ & $42 \pm 15$ & $0.6 \pm 0.5$ & $43071_{ \pm} 555$ & $8.9 \pm 0.7$ & $26 \pm 12$ & $1.4_{ \pm} 0.1$ & {$\left[3 t_{ \pm}\right]$} \\
\hline A10 & $299 \pm 31$ & $5.9+2.1$ & $27 \pm 10$ & $0.4 \pm 0.1$ & $34264 \pm 445$ & $7.1 \pm 0.6$ & $15 \pm 7$ & $1.1 \pm 0.1$ & $17_{ \pm} \pm$ \\
\hline A11 & $1898 \pm 188$ & $2.1 \pm 0.4$ & $19 \pm 7$ & $1.0 \pm 0.2$ & $563 \pm 12$ & $8.3 \pm 0.4$ & $4 \pm 2$ & $6.5 \pm 0.5$ & $65_{t}$ \\
\hline
\end{tabular}




\section{CONCLUSIONS}

Phosphogypsum samples from stacks are enriched in ${ }^{226} \mathrm{Ra},{ }^{228} \mathrm{Ra}$ and $210 \mathrm{~Pb}$, in rare-earth elements, specifically $\mathrm{Ce}, \mathrm{Eu}, \mathrm{La}, \mathrm{Nd}, \mathrm{Sm}$, and $\mathrm{Tb}$, and in elements $\mathrm{Ba}$ and $\mathrm{Ta}$. The radiochemical and elemental characterization of the phosphogypsum from industry $\mathrm{A}$ and $\mathrm{C}$ show that the stacks are quite homogeneous and mainly dependent upon the origin of the phosphatic rock used as raw material. This information is important and necessary for decision making on possible uses of this waste. The radionuclides $\mathrm{Ra}$ and $\mathrm{Pb}$, which present high radiotoxicity, although present in the phosphogypsum, are not available for the surrounding environment. Indeed, the analysis of the water from the monitor wells gave results considered not relevant.

\section{Acknowledgments}

This work was supported by Conselho Nacional de Desenvolvimento Científico e Tecnológico - CNPq, grant 300835/95-7. The samples analysed were provided by CETESB (Companhia de Tecnologia de Saneamento Ambiental).

\section{References}

[1] Borges, R.M.M., 2001. Exame de qualificação, Escola Politécnica da Universidade de São Paulo, São Paulo, 2001.

[2] Mazzilli, B.; Palmiro, V.; Saueia, C. and Nisti, B. M., 2000 Radiodhemical characterization of Brazilian phosphogysum, Journal of Environmental Radioactivity 49: 113 - 122.

[3] Custhall, N.H., Larser, I. L., Olsen, C.R., 1983 . Direct analysis of $210 \mathrm{~Pb}$ in sediment samples: selfabsorption corrections. Nuclear Instruments and methods 206: 309-312.

[4] Ministério da Saúde, (1990). Normas e Padrão de Potabilidade de Água Destinada ao Consumo Humano. Portaria n 36/GM.

[5] Oliveira, J., Mazzilli, B.P., Sampa, M.H.; Bambalas, E., 2001.Natural radionuclides in drinking water supplies of São Paulo State, Brazil and consequent population doses. Journal of Environmental Radioactivity 53: $99-109$

[6] Burnett, W.C., Elzerman, A.W., 2001. Nuclide migration and environmental radiochemistryof Florida phosphogypsum. Journal of Environmental Radioactivity 54: 27-51

[7] Azouazi, M., Ouahidi, Y. Fakhi, S., Andres, Y., Abbe, J.Ch., Benmansour, M., 2001. Natural radioactivity in phosphates, phosphogypsum and natural waters in Morocco. Journal of Environmental Radioactivity 54: 231-242.

[8] Haridasan, P.P., Paul, A.C., Desai, M.V.M., 2001. Natural radionuclides in the aquatic environment of a phosphogypsum disposal area. Journal of Environmental Radioactivity 53: 155-165. 


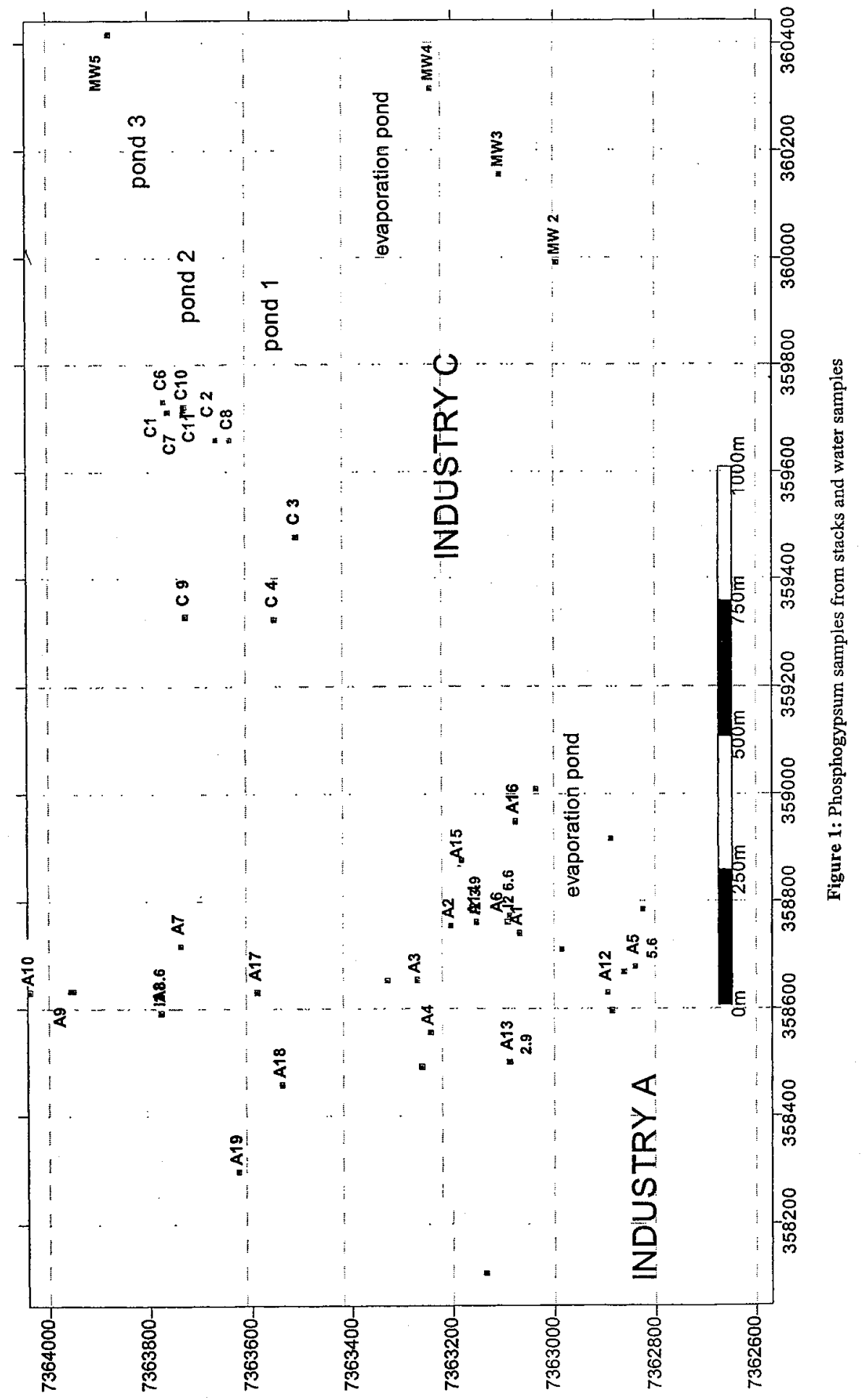




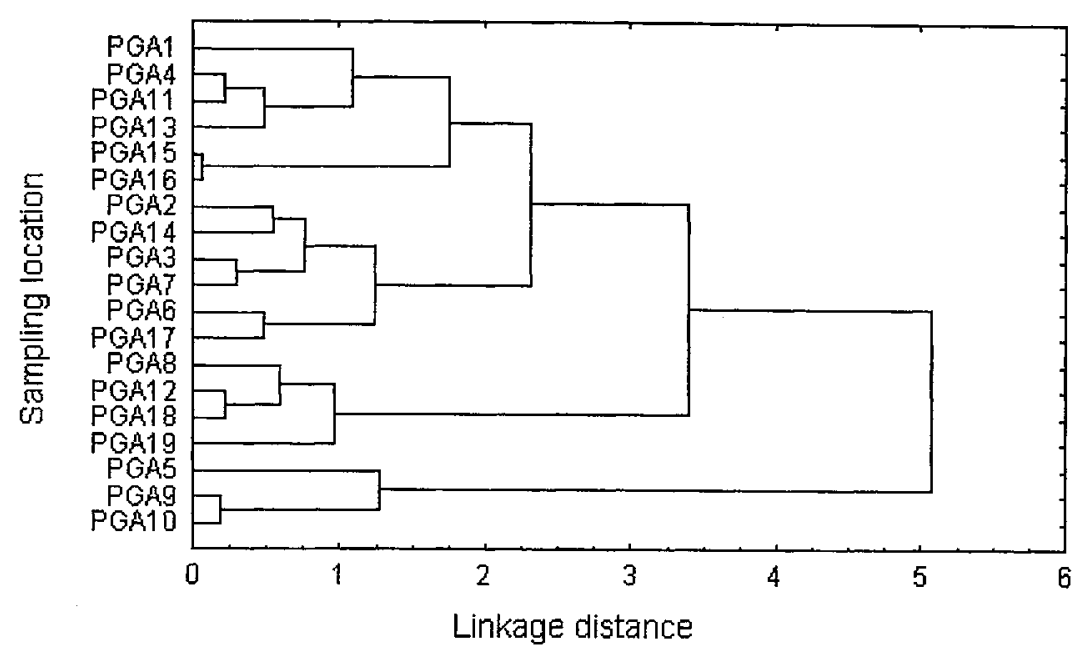

Figure 2: Cluster analysis of radionuclide concentration for industry A.

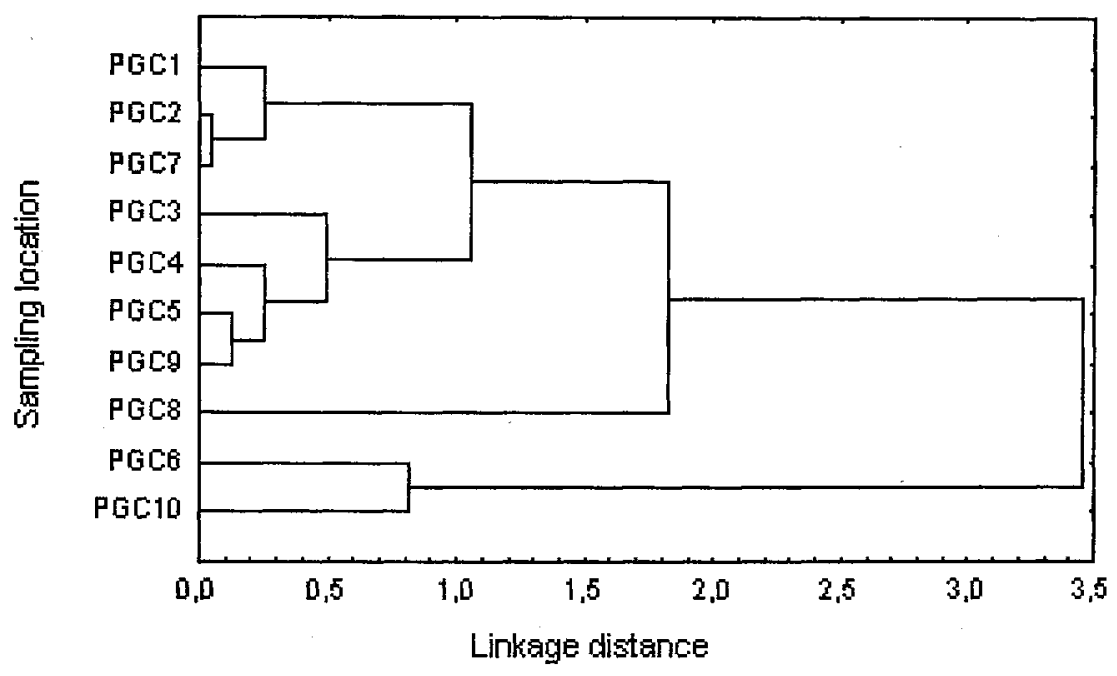

Figure 3: Cluster analysis of radionuclide concentration for industry $\mathrm{C}$. 